\title{
Heavy metal characteristics in Kočani Field plant system (Republic of Macedonia)
}

\author{
Nastja Rogan Šmuc · Tadej Dolenec • \\ Todor Serafimovski · Goran Tasev • \\ Matej Dolenec $\cdot$ Petra Vrhovnik
}

Received: 24 November 2010/Accepted: 10 November 2011/Published online: 6 December 2011

(C) Springer Science+Business Media B.V. 2011

\begin{abstract}
Heavy metal contamination of soils is widespread and induces a long-term risk to ecosystem health. This research focuses on the heavy metal contamination, transfer values and risk assessment in the Kočani Field plant system (Republic of Macedonia). To identify the heavy metal concentrations in Kočani crops (rice and maize), the geochemical analysis was performed by inductive coupled plasma mass spectrometer and thereupon the transfer factor (TF) and estimated daily intake amount values were calculated. The highest $\mathrm{As}, \mathrm{Cd}, \mathrm{Mo}, \mathrm{Pb}$ and $\mathrm{Zn}$ values were determined in the rice samples grown in the
\end{abstract}

\footnotetext{
N. R. Šmuc (四) . T. Dolenec · M. Dolenec

P. Vrhovnik

Department of Geology, Faculty of Natural Sciences and Engineering, University of Ljubljana, Aškerčeva 12, 1000 Ljubljana, Slovenia

e-mail: nastja.rogan@guest.arnes.si

T. Dolenec

e-mail: tadej.dolenec@ntf.uni-lj.si

M. Dolenec

e-mail: matej.dolenec@ntf.uni-lj.si

P. Vrhovnik

e-mail: petra.vrhovnik@gmail.com

T. Serafimovski - G. Tasev

Faculty of Natural and Technical Sciences,

"Goce Delčev" University, Goce Delčev 89,

2000 Štip, Republic of Macedonia

e-mail: todor_s2000@yahoo.co.uk

G. Tasev

e-mail: goranktasev@yahoo.com
}

paddy fields near the Zletovska River. The highest $\mathrm{Pb}$ and Mo concentrations measured in the maize samples were from the maize fields near the Zletovska River and Ciflik city. High TF values for $\mathrm{Mo}, \mathrm{Zn}, \mathrm{Cd}$ and $\mathrm{Cu}$ revealed a strong accumulation of $\mathrm{Mo}, \mathrm{Zn}$ and $\mathrm{Cd}$ by rice and $\mathrm{Mo}$ and $\mathrm{Zn}$ by maize crops. The results of the estimated daily intake showed that the regular consumption of rice and maize crops containing the highest $\mathrm{Cd}, \mathrm{Mo}, \mathrm{Pb}$ and $\mathrm{Zn}$ concentrations could pose a serious threat to human health, because the daily intake of $\mathrm{Cd}, \mathrm{Mo}, \mathrm{Pb}$ and $\mathrm{Zn}$ for crops grown in the fields around the Zletovska River exceeded the recommended provisional tolerable daily intake values. Taking into account the results, the area around Zletovska River is considered as the most anthropogenically impacted part of Kočani Field.

Keywords Heavy metals - Transfer factor - Risk assessment $\cdot$ Rice $\cdot$ Maize $\cdot$ Republic of Macedonia

\section{Introduction}

Soil is a specific component of the biosphere because it is not only treated as geochemical sink for contaminants, but also treated as a natural buffer system controlling the transport of chemical elements and substances into the biota, hydrosphere and atmosphere. It has always been important to humans and their health, especially as a resource that can be used for shelter and food production. 
Base-metal mining activities together with milling and grinding operations, concentrating ore and the disposal of tailings, acid mine and mill wastewater provide important sources of heavy metals entering into the surrounding environments (agricultural soils, food crops, riverine water and stream sediments (Adriano 1986; Jung 2001; Jung and Thornton 1997; Korre et al. 2002; Lee et al. 2001; Liu et al. 2005; Lu and Zhang 2005; Simmons et al. 2005; Witte et al. 2004, Wong et al. 2002; Yang et al. 2004). Therefore, the excessive accumulation of heavy metals in agricultural soils is a great concern because soil containing various elements is a primary nutrient medium for plants. Food crops grown in contaminated agricultural soils can accumulate elevated amounts of heavy metals, presenting a potential health risk to local inhabitants (Adriano 2001; McLaughlin et al. 1999; Pruvot et al. 2006; Zhuang et al. 2009). Several studies have reported that heavy metal pollution in mining areas have damaged the health of local inhabitants (Kachenko and Singh 2006; Liu et al. 2005). Thus, information about heavy metal concentrations in food products and their dietary intake, since this is the main route of exposure for most people, is very important for assessing the risk of heavy metals to human health.

Although mining is one of the most important industries in the Republic of Macedonia, studies about heavy metal concentrations in soils and plant crops originating from historical or current base-metal mining activities are very scarce, especially in the Kočani Field region (Dolenec et al. 2007; Rogan et al. 2009; Rogan Šmuc 2010).

Kočani Field has a long history of base-metal mining $(\mathrm{Pb}-\mathrm{Zn}$ Zletovo-Kratovo and Sasa-Toranica ore districts), and paddy rice (Oryza sativa L.) and maize (Zea mays L.) are the main agricultural products of the region. Previous study has shown that the riverine water from the Zletovska and Bregalnica Rivers, which are used to irrigate the Kočani (paddy and maize) fields, is contaminated with heavy metals as a result of the inflow of acid mine water and untreated effluents from the ore processing facilities (Zletovo-Kratovo and Sasa-Toranica ore district) (Alderton et al. 2005). Metals usually enter into agricultural soils through irrigation processes (Chen et al. 1997), and for this reason, agricultural soil and plant crops also can be contaminated, introducing risk to human and animal health. In this context, the major aims of the presented study are
- to detect the total heavy metal concentrations and distribution in food crops (rice and maize) from Kočani Field and to compare these results with permissible levels of heavy metals in crops, and

- to estimate the heavy metal uptake by food crops [transfer factor (TF)] and the potential health risks associated with the human consumption of food crops contaminated with heavy metals (estimated daily intake).

\section{Transfer factor (TF) from soil to crop}

The soil-to-plant transfer is one of the key components of human exposure to metals through the food chain. To investigate the transfer of heavy metals from soil to crops, the TF values of heavy metals studied were calculated as follows (Cui et al. 2004):

$\mathrm{TF}=C_{\text {crop }} / C_{\text {soil }}$,

where $C_{\text {crop }}$ and $C_{\text {soil }}$ signify for heavy metal concentration in the crops (rice, maize) and paddy soils, where the crops are grown on dry weight basis, respectively. In this study, we used the mean concentration values of heavy metals determined in crops (rice and maize) and paddy soils.

Dietary risk assessment (estimated daily intake amount)

The daily intake of heavy metals ( $\mathrm{Ag}, \mathrm{As}, \mathrm{Cd}, \mathrm{Cu}, \mathrm{Mo}$, $\mathrm{Ni}, \mathrm{Pb}, \mathrm{Sb}$ and $\mathrm{Zn}$ ) depends on the metal concentration in the food crops and daily food consumption. In addition, human body weight can also influence the tolerance of pollutants. The estimated daily intake amount (DI) of heavy metals for adults was determined by the following equation:

$\mathrm{DI}=[M] \times W$,

where $[M]$ is the concentration of heavy metals in the contaminated crops and $W$ signifies the daily average consumption of crops in the Kočani region. Based on an unpublished regional dietary intake survey, the average quantity consumed by an adult (70 $\mathrm{kg}$ in body weight) is $440 \mathrm{~g} \mathrm{day}^{-1}$ for rice and maize. The heavy metal intake amounts were compared with the provisional tolerable daily intake (PTDI) for an adult recommended by the WHO (1998). 


\section{Materials and methods}

Study area

Kočani Field is located in eastern Macedonia, about $32 \mathrm{~km}$ from the city of Štip and $115 \mathrm{~km}$ from the capital city Skopje. With an average length of $35 \mathrm{~km}$ and width of $5 \mathrm{~km}$, Kočani Field lies in the valley of the Bregalnica River between the Osogovo Mountains in the north and Plačkovica Mountains in the south (Fig. 1).

The broader region is well known as an agricultural and mining province, with significant thermal activity. Hot thermal waters are very convenient for the greenhouses warming. The most important agricultural products in the region are rice, maize, tomatoes, cucumbers, red peppers and other vegetables. The centre of the region, the city of Kočani, was founded on the southern foothills of the Osogovo Mountains. The municipality of the Kočani area comprises 28 settlements with 38,092 inhabitants.

The Bregalnica River, together with its tributaries (Rogan Šmuc 2010), represents the principal drainage system in the investigated area and is, therefore, an important water supply for the irrigation of the surrounding paddy fields. The main tributaries of the Bregalnica River are the Kamenica River in the northeastern part of the study area and the Zletovska River in the western side of Kočani Field (Fig. 1). The Kamenica River drains the north-eastern part of the Bregalnica River drainage basin and flows directly into the artificial Lake Kalimanci, which was constructed for the irrigation of the paddy fields during the dry season. It also drains the untreated mine effluents from the $\mathrm{Pb}-$ Zn polymetallic ore deposit Sasa (Rogan Šmuc 2010). The Zletovska River originally drained the central part of the Zletovo-Kratovo volcanic complex as well as the untreated mine effluents from the $\mathrm{Pb}-\mathrm{Zn}$ Zletovo mine and its ore processing facilities (Rogan Šmuc 2010). Both rivers are used by local farmers for the irrigation of the nearby paddy fields.

The Kočani soil mineralogy and elemental composition are closely related to the acidic and intermediate rocks of the Kočani region (Dolenec et al. 2007; Rogan Šmuc 2010).

Rice sampling and analysis

Rice grain samples (Oryza sativa L.) with hulls were collected during harvesting in November 2005 from

Fig. 1 Study area, Kočani Field (Dolenec et al. 2007)

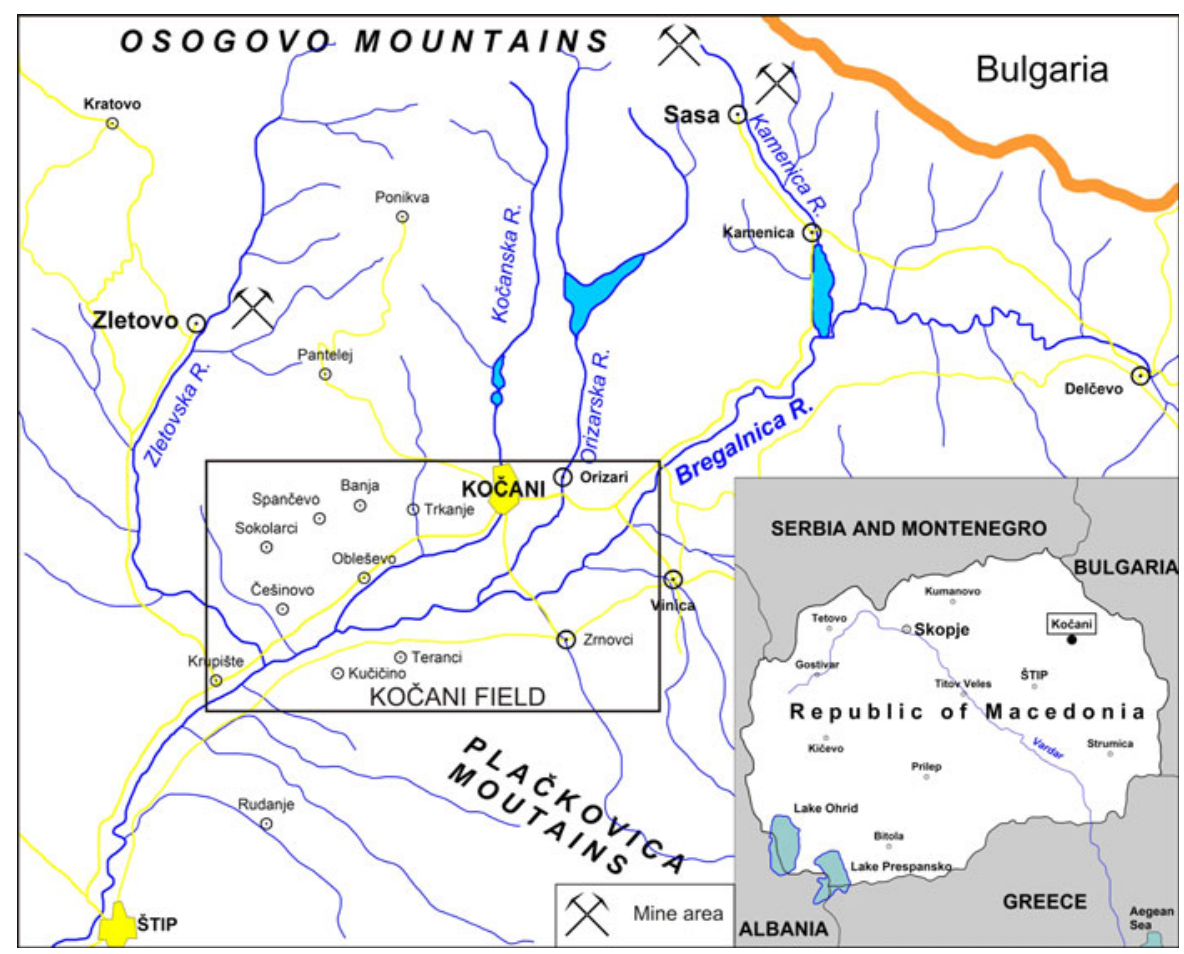


Fig. 2 Map of unpolished rice $^{\circledR}$ sampling locations

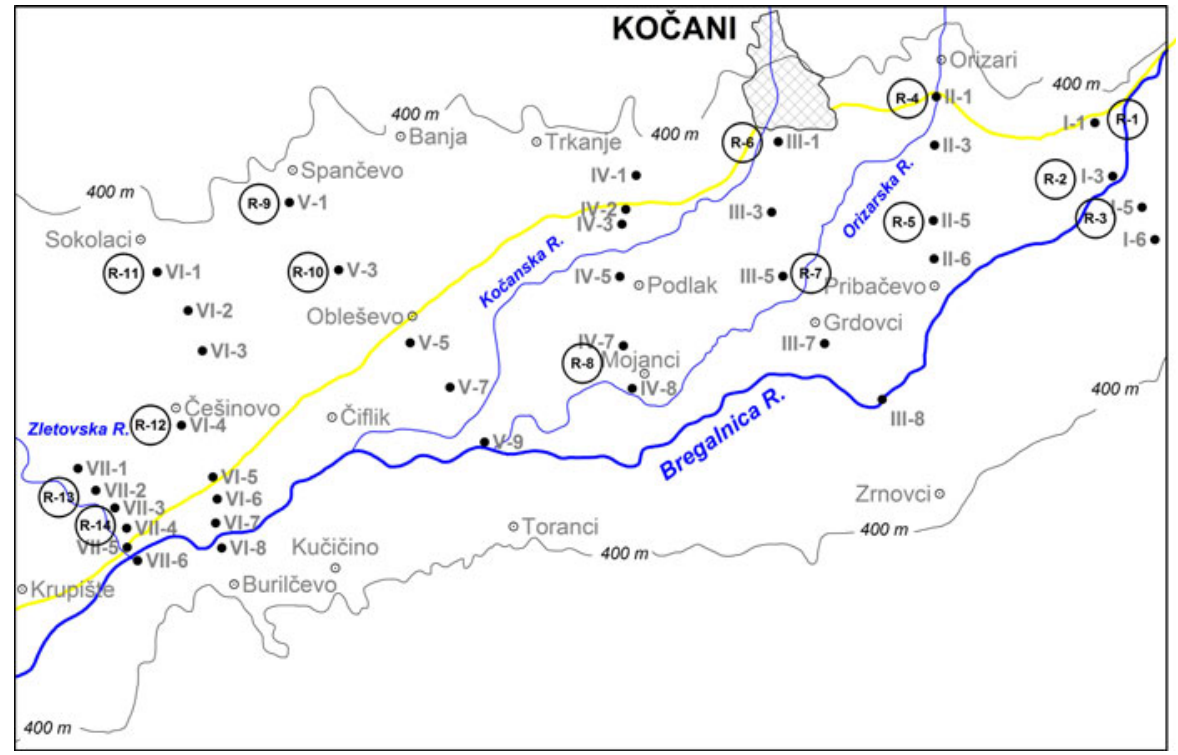

14 sampling sites across Kočani Field. Selected sampling points were located at the same approximate positions as the corresponding soil sample locations (Fig. 2).

At each sampling site, rice grains were taken from an area of $10 \times 10 \mathrm{~m}^{2}$ to obtain a final composite sample of about $1 \mathrm{~kg}$. All samples were stored in polythene bags and taken to the laboratory for further preparation and treatment.

In the laboratory, the rice samples were washed three times with the distilled water to remove soil particles and airborne pollutants and oven-dried to a constant weight at $75^{\circ} \mathrm{C}$ for $72 \mathrm{~h}$. The grains without the hull (i.e., unpolished rice) were ground into a fine powder in an agate mortar. The powdered samples were then packed in clean, dry and stoppered glass containers and stored in a refrigerator.

The geochemical analysis of the studied elements present in the investigated rice samples was carried out in a certified commercial Canadian laboratory (Acme Analytical Laboratories, Ltd). The rice samples were dissolved in environmental-grade nitric acid and then analysed by inductive coupled plasma mass spectrometer (ICP-MS). Quality control included the analysis of certified reference material (rice flour SRM 1568) from the National Bureau of Standards. The analytical precision and accuracy were better than $\pm 5 \%$ as confirmed by the results of duplicate measurements on three rice samples as well as duplicate measurements of the SRM 1568 standards.
Maize sampling and analysis

Maize grains (Zea mays L.) were sampled during harvesting in October 2008 from 15 sampling locations over Kočani Field. Sampling locations were chosen near the corresponding soil and rice samples' locations (Fig. 3).

At each sampling location, a final composite sample of about $1 \mathrm{~kg}$ (from an area of $10 \times 10 \mathrm{~m}^{2}$ ) was stored in polythene bags and taken to the laboratory for further analysis.

The maize samples were thoroughly washed in distilled water to remove organic impurities and dried in a clean room at ambient temperature for 5 days. Afterwards, the samples were milled into a fine powder and packed into clean glass containers.

The geochemical analysis of $\mathrm{Ag}, \mathrm{As}, \mathrm{Cd}, \mathrm{Cu}, \mathrm{Mo}, \mathrm{Ni}$, $\mathrm{Pb}, \mathrm{Sb}$ and $\mathrm{Zn}$ was performed in a certified commercial Canadian laboratory (Acme Analytical Laboratories, Ltd). The maize samples were digested in $\mathrm{HNO}_{3}$ (aqua regia) and analysed by ICP-MS. The analytical precision and accuracy were better than $\pm 5 \%$. In addition, they were confirmed by the results of duplicate measurements on three corn grain samples as well as duplicate measurements of the SRM 1568 standards.

Statistical analysis

To investigate the elemental associations among the analysed elements in rice and maize samples, Pearson 
Fig. 3 Map of maize (C) sampling locations

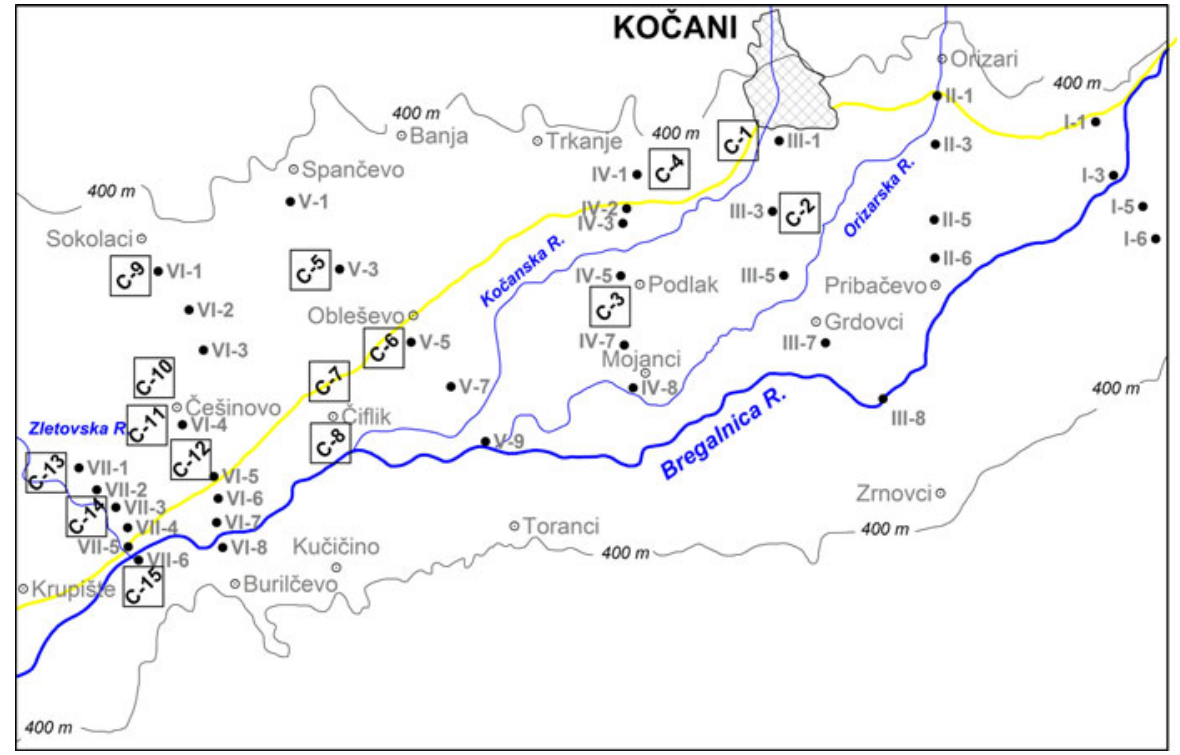

$R$ correlation analyses were applied to all samples studied. Critical values of the correlation coefficients ( $r$ ) were 0.36 at $p \leq 0.05,0.43$ at $p \leq 0.01,0.93$ at $p \leq 0.005$ and 0.91 at $p \leq 0.001$. Results that yielded $p \leq 0.05$ were considered borderline significant, whereas those at $p \leq 0.01$ were denoted significant. Results at $p \leq 0.005$ or $p \leq 0.001$ levels were evaluated as highly significant.

The basic statistical parameters for each element and the statistical calculations mentioned above were computed by the statistical software program (Statistica VI).

\section{Results and discussion}

Heavy metal concentrations in rice and maize

Table 1 summarises the concentrations of $\mathrm{As}, \mathrm{Cd}, \mathrm{Cu}$, $\mathrm{Mo}, \mathrm{Pb}$ and $\mathrm{Zn}$ in unpolished rice (Oryza sativa $\mathrm{L}$.) grown on the paddy fields of Kočani Field together with the maximum permissible limits of analysed heavy metal concentrations in food crops adopted by various international and national agencies. $\mathrm{Ag}, \mathrm{Ni}$ and $\mathrm{Sb}$ concentrations were not detected and, therefore, not taken into account.

Table 2 shows a synthesis of the main statistical parameters (mean, median, range and SD) for the unpolished rice samples.
Maize grains (Zea mays L.) cultivated in the paddy soils of Kočani Field were also not free from the heavy metal contamination. Table 3 displays the total concentrations of $\mathrm{Cd}, \mathrm{Cu}, \mathrm{Mo}, \mathrm{Ni}, \mathrm{Pb}$ and $\mathrm{Zn}$ in the maize grain samples collected together with the maximum permissible limits of analysed concentrations in food crops proposed by different international agencies. The total concentrations of $\mathrm{Ag}$, As and Sb were below the detection limit. Table 4 gives the descriptive statistical parameters (mean, median, range and SD).

\section{Arsenic (As)}

The As concentrations in unpolished rice found in this study were in the range from 0.15 to $0.53 \mathrm{mg} \mathrm{kg}^{-1}$, with a mean value of $0.28 \mathrm{mg} \mathrm{kg}^{-1}$ (Tables 1,2 ). The highest concentrations (up to $0.53 \mathrm{mg} \mathrm{kg}^{-1}$ ) were measured in rice samples grown in the paddy soils from Section VII, close to the Zletovska River (Table 1). However, these values were up to 2.7 times higher than the corresponding limit level of $0.2 \mathrm{mg} \mathrm{kg}^{-1}$ for food plants (Pilc et al. 1994).

\section{Cadmium $(C d)$}

In our study, the $\mathrm{Cd}$ concentrations in the rice samples varied from 0.005 to $0.310 \mathrm{mg} \mathrm{kg}^{-1}$, with a median value of $0.069 \mathrm{mg} \mathrm{kg}^{-1}$ (Tables 1, 2). Around Zletovska River area (Section VII), the Cd concentrations 
Table 1 The total concentrations of As, Cd, $\mathrm{Cu}, \mathrm{Mo}, \mathrm{Pb}$, and $\mathrm{Zn}$ in unpolished rice (Oryza sativa L.) samples from Kočani Field

\begin{tabular}{|c|c|c|c|c|c|c|}
\hline Element $(\mathrm{mg} / \mathrm{kg})$ & As & $\mathrm{Cd}$ & $\mathrm{Cu}$ & Mo & $\mathrm{Pb}$ & $\mathrm{Zn}$ \\
\hline \multicolumn{7}{|l|}{ Location } \\
\hline $\mathrm{R}-1$ & 0.30 & 0.010 & 3,8 & 0.6 & 0.1 & 31 \\
\hline R-2 & 0.28 & 0.140 & 4,5 & 0.6 & 0.2 & 37 \\
\hline $\mathrm{R}-3$ & 0.22 & 0.020 & 3.8 & 0.6 & 0.2 & 28 \\
\hline $\mathrm{R}-4$ & 0.24 & 0.040 & 2.7 & 0.3 & 0.2 & 22 \\
\hline $\mathrm{R}-5$ & 0.22 & 0.010 & 2.1 & 0.3 & 0.1 & 21 \\
\hline R-6 & 0.18 & 0.070 & 4.7 & 0.6 & 0.3 & 26 \\
\hline $\mathrm{R}-7$ & 0.19 & 0.010 & 1.2 & 0.3 & 0.2 & 26 \\
\hline $\mathrm{R}-8$ & 0.42 & 0.010 & 2.0 & 0.3 & 0.1 & 15 \\
\hline $\mathrm{R}-9$ & 0.28 & 0.150 & 3.2 & 0.6 & 0.1 & 31 \\
\hline $\mathrm{R}-10$ & 0.33 & 0.010 & 1.3 & 0.2 & 0.1 & 19 \\
\hline $\mathrm{R}-11$ & 0.16 & 0.005 & 1.2 & 0.3 & 0.05 & 16 \\
\hline $\mathrm{R}-12$ & 0.15 & 0.005 & 0.8 & 0.4 & 0.1 & 13 \\
\hline $\mathrm{R}-13$ & 0.40 & 0.180 & 4.9 & 0.7 & 0.4 & 38 \\
\hline R-14 & 0.53 & 0.310 & 5.8 & 0.6 & 0.5 & 67 \\
\hline 1 & - & 0.1 & - & - & 0.2 & - \\
\hline 2 & - & - & 10 & 0.5 & - & - \\
\hline 3 & 0.2 & 0.15 & - & - & 1.0 & 50 \\
\hline
\end{tabular}

Table 2 Descriptive basic statistic of the elemental content in unpolished rice from Kočani Field

\begin{tabular}{lllllll}
\hline Element $(\mathrm{mg} / \mathrm{kg})$ & $\mathrm{As}$ & $\mathrm{Cd}$ & $\mathrm{Cu}$ & $\mathrm{Mo}$ & $\mathrm{Pb}$ & $\mathrm{Zn}$ \\
\hline Mean & 0.279 & 0.069 & 3.00 & 0.46 & 0.19 & 27.86 \\
Median & 0.260 & 0.015 & 2.95 & 0.50 & 0.15 & 26.00 \\
Minimum & 0.150 & 0.005 & 0.80 & 0.20 & 0.05 & 13.00 \\
Maximum & 0.530 & 0.310 & 5.80 & 0.70 & 0.50 & 67.00 \\
SD & 0.110 & 0.092 & 1.62 & 0.17 & 0.13 & 13.68 \\
\hline
\end{tabular}

in unpolished rice samples exceeded the internationally recognised maximum level for $\mathrm{Cd}$ in rice grains of $0.2 \mathrm{mg} \mathrm{kg}^{-1}$ (CAC 2002) as well as the maximum permitted level of $0.1 \mathrm{mg} \mathrm{kg}^{-1}$ in cereals given by the Commission Regulation Directive EC (2001) (Table 1).

The concentrations of $\mathrm{Cd}$ in maize grains were similar to the background levels of $\mathrm{Cd}$ in cereal grains reported by Kabata-Pendias and Pendias (2001) (Tables 3, 4). Cd concentrations in the maize grains samples did not exceed the maximum permissible limits defined by the Commission Regulation Directive EC (2001) or the corresponding limit given by Pilc et al. (1994).

\section{Copper (Cu)}

The concentrations of $\mathrm{Cu}$ measured in the rice samples from Kočani Field ranged between 0.8 and $5.8 \mathrm{mg} \mathrm{kg}^{-1}$, with a mean value of $3 \mathrm{mg} \mathrm{kg}^{-1}$ (Tables 1 , 2). $\mathrm{Cu}$ concentration in unpolished rice did not exceed the maximum permissible limit of $10 \mu \mathrm{g} \mathrm{g}^{-1}$ (WHO 1998).

The concentrations of $\mathrm{Cu}$ in the maize samples varied from 0.76 to $1.98 \mathrm{mg} \mathrm{kg}^{-1}$, with a mean value of $1.47 \mathrm{mg} \mathrm{kg}^{-1}$ (Tables 3, 4). However, the measured $\mathrm{Cu}$ concentrations in maize grains did not exceed the maximum permissible limit (WHO 1998). 
Table 3 Total $\mathrm{Cd}, \mathrm{Cu}$, $\mathrm{Mo}, \mathrm{Ni}, \mathrm{Pb}$ and $\mathrm{Zn}$ concentrations in maize (Zea mays L.) samples from Kočani Field

\begin{tabular}{lllllll}
\hline Element $(\mathrm{mg} / \mathrm{kg})$ & $\mathrm{Cd}$ & $\mathrm{Cu}$ & $\mathrm{Mo}$ & $\mathrm{Ni}$ & $\mathrm{Pb}$ & $\mathrm{Zn}$ \\
\hline Location & & & & & & \\
C1 & 0.07 & 1.98 & 0.09 & 0.5 & 0.07 & 21.5 \\
C2 & 0.07 & 1.65 & 0.02 & 0.5 & 0.07 & 24.1 \\
C3 & 0.01 & 0.76 & 0.38 & 0.1 & 0.07 & 22.7 \\
C4 & 0.07 & 1.24 & 0.27 & 0.2 & 0.07 & 21.6 \\
C5 & 0.07 & 0.96 & 0.43 & 0.2 & 0.07 & 21.7 \\
C6 & 0.07 & 1.45 & 0.63 & 0.2 & 0.03 & 20.5 \\
C7 & 0.07 & 1.77 & 0.73 & 0.3 & 0.43 & 25.1 \\
C8 & 0.07 & 1.70 & 0.65 & 0.2 & 0.07 & 22.0 \\
C9 & 0.07 & 1.86 & 0.48 & 0.2 & 0.34 & 24.2 \\
C10 & 0.07 & 1.65 & 0.24 & 0.7 & 0.07 & 21.4 \\
C11 & 0.07 & 1.4 & 0.41 & 0.1 & 0.11 & 20.3 \\
C12 & 0.01 & 1.16 & 0.36 & 0.2 & 1.38 & 21.8 \\
C13 & 1.58 & 0.32 & 0.2 & 0.16 & 20.3 \\
C14 & 0.02 & 1.55 & 0.22 & 0.7 & 0.08 & 32.3 \\
C15 & 0.02 & 1.27 & 0.32 & 0.3 & 0.36 & 20.3 \\
1 & 0.07 & - & - & - & 0.2 & - \\
2 & 0.1 & 10 & 0.5 & 0.5 & - & - \\
3 & - & - & - & 1.0 & 50 \\
\hline
\end{tabular}

Table 4 Basic statistic parameters of the elemental content in maize samples from Kočani Field

\begin{tabular}{lllllrr}
\hline Element $(\mathrm{mg} / \mathrm{kg})$ & $\mathrm{Cd}$ & $\mathrm{Cu}$ & $\mathrm{Mo}$ & $\mathrm{Ni}$ & $\mathrm{Pb}$ & $\mathrm{Zn}$ \\
\hline Mean & 0.008 & 1.465 & 0.370 & 0.222 & 0.195 & 22.653 \\
Median & 0.006 & 1.550 & 0.360 & 0.200 & 0.030 & 21.700 \\
Minimum & 0.006 & 0.760 & 0.020 & 0.066 & 0.006 & 20.300 \\
Maximum & 0.020 & 1.980 & 0.730 & 0.500 & 1.380 & 32.300 \\
SD & 0.005 & 0.338 & 0.198 & 0.133 & 0.359 & 3.057 \\
\hline
\end{tabular}

\section{Lead $(P b)$}

The range and mean concentrations of $\mathrm{Pb}$ in rice sampled during this study were $0.05-0.5$ and $0.196 \mathrm{mg} \mathrm{kg}^{-1}$, respectively (Tables 1,2 ). The highest $\mathrm{Pb}$ content (Table 1) was measured in the rice samples grown on the paddy soils in Section VII. The detected values showed that $\mathrm{Pb}$ concentrations in these rice samples were higher than the maximum permitted levels of $0.2 \mathrm{mg} \mathrm{kg}^{-1}$ for food crops reported by the Environmental Protection Agency of Slovenia (Table 1).

The $\mathrm{Pb}$ concentrations in maize grains measured during this study were in the range $0.007-1.38 \mathrm{mg} \mathrm{kg}^{-1}$, with a mean value of $0.2 \mathrm{mg} \mathrm{kg}^{-1}$ (Tables 3, 4). Four samples collected from the vicinity of the Zletovska River (Section VII) exhibited higher values of $\mathrm{Pb}$ according to the corresponding maximum limits of $\mathrm{Pb}$ for plants used for food (Table 3).

\section{Molybdenum (Mo)}

Mo concentrations in unpolished rice from Kočani Field (range $0.2-0.7 \mathrm{mg} \mathrm{kg}^{-1}$ ) were much higher than the average values for Mo in the cereal grains (around $0.49 \mathrm{mg} \mathrm{kg}^{-1}$ ) especially in the rice samples from Section VII (Tables 1, 2).

The concentrations of Mo in the maize grains from Kočani Field ranged from 0.02 to $0.73 \mathrm{mg} \mathrm{kg}^{-1}$ 
Table 5 Pearson's correlation matrix between heavy metals in unpolished rice samples (marked correlations are significant at $p<0.05)$

\begin{tabular}{lllllll}
\hline & As & Cd & Cu & Mo & Pb & Zn \\
\hline $\mathrm{As}$ & 1.00 & $\mathbf{0 . 6 8}$ & 0.53 & 0.27 & $\mathbf{0 . 5 6}$ & $\mathbf{0 . 6 7}$ \\
$\mathrm{Cd}$ & $\mathbf{0 . 6 8}$ & 1.00 & $\mathbf{0 . 7 8}$ & 1.00 & $\mathbf{0 . 6 3}$ & $\mathbf{0 . 9 1}$ \\
$\mathrm{Cu}$ & 0.53 & $\mathbf{0 . 7 8}$ & $\mathbf{0 . 8 5}$ & 1.00 & $\mathbf{0 . 7 8}$ & $\mathbf{0 . 5 7}$ \\
$\mathrm{Mo}$ & 0.27 & $\mathbf{0 . 6 3}$ & $\mathbf{0 . 7 8}$ & $\mathbf{0 . 5 7}$ & 1.00 & $\mathbf{0 . 6 4}$ \\
$\mathrm{Pb}$ & $\mathbf{0 . 5 6}$ & $\mathbf{0 . 8 1}$ & $\mathbf{0 . 8 2}$ & $\mathbf{0 . 6 4}$ & $\mathbf{0 . 8 2}$ \\
$\mathrm{Zn}$ & $\mathbf{0 . 6 7}$ & & & & 1.00 \\
\hline
\end{tabular}

Table 6 Pearson's correlation matrix between heavy metals in maize samples

\begin{tabular}{|c|c|c|c|c|c|c|}
\hline & $\mathrm{Cd}$ & $\mathrm{Cu}$ & Mo & $\mathrm{Pb}$ & $\mathrm{Zn}$ & $\mathrm{Ni}$ \\
\hline $\mathrm{Cd}$ & 1.00 & -0.05 & -0.21 & 0.08 & 0.47 & -0.34 \\
\hline $\mathrm{Cu}$ & -0.05 & 1.00 & -0.04 & -0.12 & 0.19 & 0.42 \\
\hline Mo & -0.21 & -0.04 & 1.00 & 0.15 & -0.11 & -0.34 \\
\hline $\mathrm{Pb}$ & 0.08 & -0.12 & 0.15 & 1.00 & -0.03 & -0.01 \\
\hline $\mathrm{Zn}$ & 0.47 & 0.19 & -0.11 & -0.03 & 1.00 & -0.14 \\
\hline $\mathrm{Ni}$ & -0.34 & 0.42 & -0.34 & -0.01 & -0.14 & 1.00 \\
\hline
\end{tabular}

(mean $0.37 \mathrm{mg} \mathrm{kg}^{-1}$, Tables 3, 4). The determined values in the maize samples collected in the vicinity of the Ciflik city (Section V) also exceeded the typical global Mo content in cereals $\left(0.49 \mathrm{mg} \mathrm{kg}^{-1}\right)$ reported by Kabata-Pendias and Pendias (2001) (Table 4).

\section{Zinc (Zn)}

The $\mathrm{Zn}$ concentrations in rice measured during this study were in the range from 13 to $67 \mathrm{mg} \mathrm{kg}^{-1}$, with a mean value of $27.86 \mathrm{mg} \mathrm{kg}^{-1}$ (Tables 1, 2). Taking into account the two limits proposed for $\mathrm{Zn}$ concentrations in crops, only one sample close to the Zletovska River (Table 1) exceeded the concentration limit proposed for food crops.

The range and mean concentrations of $\mathrm{Zn}$ in maize grains were found to be $20.3-32.3$ and $22.7 \mathrm{mg} \mathrm{kg}^{-1}$, respectively (Tables 3,4$)$. $\mathrm{Zn}$ concentrations in the maize grains were in the range of the maximum permissible international limits for heavy metals in food crops (Table 3).

The Pearson correlation coefficient matrix between heavy metals in unpolished rice samples is presented in Table 5. In general, $\mathrm{Cd}, \mathrm{Cu}, \mathrm{Pb}, \mathrm{Zn}, \mathrm{Cu}$ and $\mathrm{Mo}$ were highly significantly correlated with each other in all unpolished rice samples. $\mathrm{Cd}, \mathrm{Pb}, \mathrm{Zn}$ and Mo were significantly associated with $\mathrm{As}, \mathrm{Cd}, \mathrm{Pb}$ and $\mathrm{Zn}$. These associations could be suggested by their common geochemical characteristics and input sources. By contrast, there was no connection between $\mathrm{As}, \mathrm{Cu}$ and Mo, indicating that these relationships were insignificant.

The coefficient matrix among heavy metals in maize grain samples is displayed in Table 6, showing no significant relationships and negative correlations between heavy metals studied. Thus, the associations between heavy metals studied in maize grains were not important.

Heavy metal accumulation in crops can be influenced by various factors including the total or extractable contents of elements in soils, soil $\mathrm{pH}$, organic matter contents of soils, soil texture, plant species, plant part and age and climatic conditions. Concentrations of heavy metals in soils, whether total or extractable, are the most important factors affecting the elemental concentrations and uptake by plants. Although the extent of heavy metal uptake by plants varies because of several different factors, it has been well documented that the concentrations of heavy metals in crop plants are closely related to heavy metal levels in the soil (Adriano 1986; Cheng et al. 2006; Li and Thornton 1993).

The As, $\mathrm{Cd}, \mathrm{Cu}, \mathrm{Pb}$ and $\mathrm{Zn}$ concentrations determined in the paddy soils from Section VII, located in 
the vicinity of the Zletovska River and ZletovoKratovo ore district, significantly exceeded maximum permissible levels (Dolenec et al. 2007; Rogan et al. 2009; Rogan Šmuc 2010). The pollution in Section VII is undoubtedly related to the irrigation of the paddy fields with the riverine water from the Zletovska River, which drains acidic mine waters and untreated mining waste effluents from the Zletovo-Kratovo mine (Alderton et al. 2005). Elevated concentrations of $\mathrm{As}, \mathrm{Cd}, \mathrm{Cu}, \mathrm{Pb}$ and $\mathrm{Zn}$ were observed in other paddy soil sections (especially Sections V and VI) as well (Dolenec et al. 2007). This elevation originates from the discharges of the untreated municipal and domestic waste from the city of Kočani and the village of Orizari into the riverine systems of the Kočanska and Orizarska Rivers, which are both used for irrigation purposes (Dolenec et al. 2007). Although the concentrations of Mo were below the maximum permissible levels, their enrichment in the paddy soil samples near the Zletovska River was also noticeable (Dolenec et al. 2007; Rogan et al. 2009; Rogan Šmuc 2010).

Consequently, the highest $\mathrm{As}, \mathrm{Cd}, \mathrm{Mo}, \mathrm{Pb}$ and $\mathrm{Zn}$ values, which exceed the maximum permissible levels, were detected in the rice samples grown in the paddy fields near the Zletovska River (Section VII). The highest $\mathrm{Pb}$ and Mo concentrations, which also exceeded the maximum permissible values, were present in the maize samples from the corn fields near the Zletovska River $(\mathrm{Pb})$ and Ciflik city (Mo). This situation is associated with the abovementioned fact that paddy soils located in the vicinity of the Zletovska River contained very high amounts of these heavy metals (Dolenec et al. 2007; Rogan et al. 2009; Rogan Šmuc 2010). Moreover, the locations around the city of Ciflik are probably polluted with Mo not only due to irrigation from the polluted riverine water, but also from traffic and geogenic Mo sources (Rogan Šmuc 2010).

The results indicated that only the $\mathrm{Cu}$ content in rice samples from Kočani Field do not exceed the maximum permissible level in food crops. $\mathrm{Cd}, \mathrm{Cu}, \mathrm{Ni}$ and $\mathrm{Zn}$ contents in the maize samples were also in the range of the maximum permissible international limits for heavy metal in food crops.

According to the results of the heavy metal concentrations present in the paddy soil, rice and maize, the area around Zletovska River is considered the most anthropogenically impacted part of Kočani Field. The elevated concentrations of the analysed heavy metals are undoubtedly related to past and present mining activities, especially in the ZletovoKratovo ore district.

It is generally known that heavy metal concentrations in plants vary within plant species (Adriano 1986; Alloway 1990). The root tissue usually contains the highest heavy metal concentrations, followed by the leaf, stalk and grain (Jung and Thornton 1996; Lee et al. 2001). Leafy vegetables tend to accumulate higher metal concentrations than the root, grain or fruit crops (Alloway 1990; Jung and Thornton 1996; Zhuang et al. 2009).

For these reasons, the heavy metal concentrations in rice samples in our study were generally higher than those in maize samples. The distinction between heavy metals determined in rice and maize could also be explained by the following facts. Rice grains were sampled in 2005, when the pollution law about mining activities was not yet in place and when the anthropogenic effects from the Sasa tailing dam accident remained high (Rogan Šmuc et al. 2009). Maize grain samples were collected in 2008, when the law had been passed and the effects of the Sasa tailing dam accident had decreased. Consequently, heavy metal concentrations determined in rice samples were significantly higher than the heavy metal amounts measured in maize grain samples.

Transfer factor (TF) from soil to crop (rice and maize)

Figures 4 and 5 show the TF values calculated for heavy metal transfer from soils to rice and maize grains.

Soil to plant TF is one of the main components of human exposure to metals through the food chain, and it could reflect bioavailability of heavy metals in investigated soils. The higher the TF values are, the more mobile/available the metal is (Dean 2007; Cui et al. 2004; Khan et al. 2008). For an individual heavy metal, the TFs vary greatly within the plant species (Cui et al. 2004). There was a significant difference in $\mathrm{TF}$ values among the rice and maize crops. The TF values for heavy metals in maize samples were generally lower, principally because the heavy metal concentrations detected were also lower than those in the rice grains (Tables 1, 3).

Mean TF values for heavy metals including As, Cd, $\mathrm{Cu}, \mathrm{Mo}, \mathrm{Pb}$ and $\mathrm{Zn}$ in rice samples were $0.03,0.15$, 


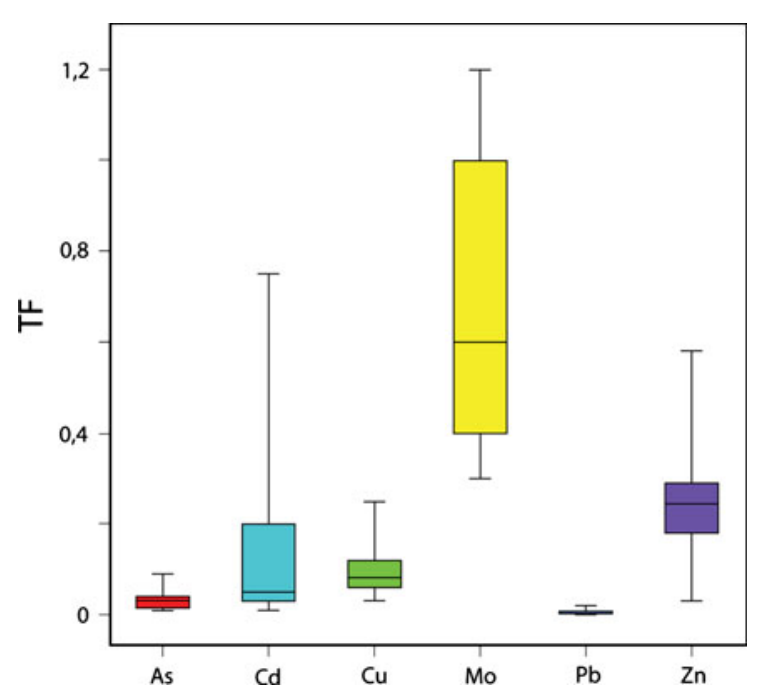

Fig. 4 TF values for heavy metals in rice samples

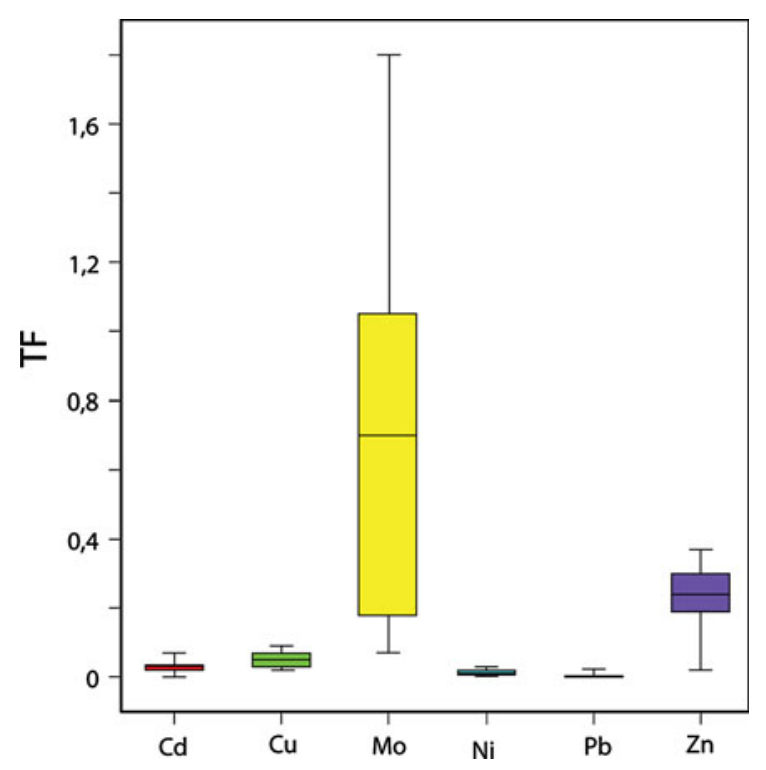

Fig. 5 TF values for heavy metals in maize samples

$0.1,0.7,0.01$ and 0.37 , respectively, showing medium accumulation of respective metals by studied crops (Dean 2007; Cui et al. 2004; Khan et al. 2008). The trends in the TF values for heavy metals in rice crops were in the descending order: $\mathrm{Mo}>\mathrm{Zn}>\mathrm{Cd}>$ $\mathrm{Cu}>\mathrm{As}>\mathrm{Pb}$. The results for TF values of heavy metals in maize crops were 0.03 for $\mathrm{Cd}, 0.05$ for $\mathrm{Cu}$, 0.76 for Mo, 0.01 for $\mathrm{Ni}, 0.004$ for $\mathrm{Pb}$ and 0.2 for $\mathrm{Zn}$. These values indicated low and medium accumulation values of metals by maize crops (Dean 2007; Cui et al.
2004; Khan et al. 2008). The trends for the TF for heavy metals in maize crops were in order of $\mathrm{Mo}>\mathrm{Zn}>\mathrm{Cu}>\mathrm{Cd}>\mathrm{Ni}>\mathrm{Pb}$. Therefore, the high $\mathrm{TF}$ values for $\mathrm{Mo}, \mathrm{Zn}, \mathrm{Cd}$ and $\mathrm{Cu}$ revealed a medium accumulation (soil-crop) of Mo, $\mathrm{Zn}$ and $\mathrm{Cd}$ by rice and $\mathrm{Mo}, \mathrm{Zn}$ and $\mathrm{Cu}$ by maize crops.

The pattern of the TF values in our study decreased with increasing total metal concentrations in soils, indicating an inverse relationship between $\mathrm{TF}$ and total metal concentrations in soils. This was also recognised by Khan et al. (2008) and Wang et al. (2006).

Similarly, we performed Pearson's correlation analysis to identify the relationships between the heavy metal concentrations in soil (Rogan Šmuc 2010) and rice samples (Table 7). Highly positive correlations were established for $\mathrm{As}, \mathrm{Cd}, \mathrm{Cu}, \mathrm{Pb}$ and $\mathrm{Zn}$, whereas there was no association present with $\mathrm{Mo}$ and other heavy metals. The results revealed that $\mathrm{As}, \mathrm{Cd}$, $\mathrm{Cu}, \mathrm{Pb}$ and $\mathrm{Zn}$ in soil and rice samples have similar geochemical characteristics and behaviour. The correlation between Mo and other heavy metals determined in soil and rice samples was unsignificant.

Table 8 presents the relationships between heavy metal content in soil (Rogan Šmuc 2010) and maize samples. The correlation matrix exhibited significant correlations for $\mathrm{Cd}$ with $\mathrm{Cu}, \mathrm{Mo}, \mathrm{Pb}$ and $\mathrm{Zn}$ and for $\mathrm{Zn}$ with $\mathrm{Cu}$, denoting their similar geochemical characteristics and behaviour in soils and maize grains from Kočani Field. Negative and insignificant relationships were observed with all other heavy metals present in soil and maize samples.

The $\mathrm{TF}$ results $(\mathrm{Mo}>\mathrm{Zn}>\mathrm{Cu}>\mathrm{Cd}>\mathrm{Ni}>\mathrm{Pb})$ generally confirmed the sequential extraction results, where the mobility of the heavy metals studied was estimated to be in the following order: $\mathrm{Cd}>\mathrm{Mo}>$ $\mathrm{Sb}>\mathrm{Zn}>\mathrm{Cu}>\mathrm{As}>\mathrm{Pb}>\mathrm{Ni}>\mathrm{Ag}$ (Rogan $\breve{S} m u c$ 2010).

Interesting fact was why the TF values for Mo and $\mathrm{Zn}$ prevailed over $\mathrm{Cd}$, especially if we compare them with the results of the sequential extraction study. In particular, no direct evidence exists about Mo active uptake. Mo is moderately mobile in plants, but the form of Mo translocation is unknown (Kabata-Pendias and Pendias 2001). But the paddy soils studied were characterised as well-aerated (oxidising) acid soils $(\mathrm{pH}=5.5)$ (Rogan Šmuc 2010), which means that Mo could be easily mobile and available to plants (Rose et al. 1979). Roots often contain much more $\mathrm{Zn}$ than 
Table 7 Pearson's correlation matrix for relationship between total heavy metals content in paddy soil and unpolished rice samples (marked correlations are significant at $p<0.05$ )

\begin{tabular}{lllllll}
\hline Ricelsoil $(\mathrm{S})$ & $\mathrm{As}(\mathrm{S})$ & $\mathrm{Cd}(\mathrm{S})$ & $\mathrm{Cu}(\mathrm{S})$ & $\mathrm{Mo}(\mathrm{S})$ & $\mathrm{Pb}(\mathrm{S})$ & $\mathrm{Zn}(\mathrm{S})$ \\
\hline $\mathrm{As}$ & $\mathbf{0 . 7 3}$ & $\mathbf{0 . 7 3}$ & $\mathbf{0 . 6 1}$ & $\mathbf{0 . 7 9}$ & $\mathbf{0 . 7 3}$ & $\mathbf{0 . 7 2}$ \\
$\mathrm{Cd}$ & $\mathbf{0 . 8 9}$ & $\mathbf{0 . 8 4}$ & $\mathbf{0 . 7 6}$ & $\mathbf{0 . 8 9}$ & $\mathbf{0 . 8 3}$ & $\mathbf{0 . 8 4}$ \\
$\mathrm{Cu}$ & $\mathbf{0 . 6 4}$ & $\mathbf{0 . 6 3}$ & $\mathbf{0 . 6 1}$ & $\mathbf{0 . 7 1}$ & $\mathbf{0 . 6 3}$ & $\mathbf{0 . 6 3}$ \\
$\mathrm{Mo}$ & 0.50 & 0.48 & 0.51 & $\mathbf{0 . 5 7}$ & 0.49 & 0.49 \\
$\mathrm{~Pb}$ & $\mathbf{0 . 8 5}$ & $\mathbf{0 . 8 6}$ & $\mathbf{0 . 8 6}$ & $\mathbf{0 . 8 5}$ & $\mathbf{0 . 8 6}$ & $\mathbf{0 . 8 7}$ \\
$\mathrm{Zn}$ & $\mathbf{0 . 8 2}$ & $\mathbf{0 . 8 0}$ & $\mathbf{0 . 6 9}$ & $\mathbf{0 . 8 1}$ & $\mathbf{0 . 7 9}$ & $\mathbf{0 . 7 9}$ \\
\hline
\end{tabular}

Table 8 Pearson's correlation coefficients for relationship between total heavy metals concentrations in paddy soil and maize samples (marked correlations are significant at $p<0.05$ )

\begin{tabular}{lrrrrrr}
\hline Corn!soil (S) & $\mathrm{Cd}(\mathrm{S})$ & $\mathrm{Cu}(\mathrm{S})$ & $\mathrm{Mo}(\mathrm{S})$ & $\mathrm{Pb}(\mathrm{S})$ & $\mathrm{Zn}(\mathrm{S})$ & $\mathrm{Ni}(\mathrm{S})$ \\
\hline $\mathrm{Cd}$ & $\mathbf{0 . 5 3}$ & -0.04 & -0.23 & 0.04 & 0.36 & -0.10 \\
$\mathrm{Cu}$ & $\mathbf{0 . 6 2}$ & -0.01 & -0.34 & -0.04 & $\mathbf{0 . 5 2}$ & -0.17 \\
$\mathrm{Mo}$ & $\mathbf{0 . 6 4}$ & -0.17 & -0.26 & -0.03 & 0.29 & -0.21 \\
$\mathrm{~Pb}$ & $\mathbf{0 . 5 5}$ & -0.05 & -0.22 & 0.04 & 0.37 & -0.12 \\
$\mathrm{Zn}$ & $\mathbf{0 . 5 4}$ & -0.05 & -0.23 & 0.03 & 0.37 & -0.11 \\
$\mathrm{Ni}$ & -0.39 & 0.17 & -0.33 & -0.07 & -0.13 & 0.24 \\
\hline
\end{tabular}

plant tops, but with the luxury levels of soil $\mathrm{Zn}$ might be translocated from the roots and accumulated in the plant tops (Kabata-Pendias and Pendias 2001). On the contrary, a greater proportion of $\mathrm{Cd}$ is known to be accumulated in root tissues, although $\mathrm{Cd}$ present in plants is relatively mobile (Kabata-Pendias and Pendias 2001). Because there is no information about the heavy metal concentrations present in the rice and maize roots, we concluded that (1) according to the other elements studied, Mo was highly mobile in the plants growing in the Kočani Field area, (2) very high amounts (luxury levels) of $\mathrm{Zn}$ were measured in the Kočani paddy soil (Rogan Šmuc 2010) and the translocation process from roots to plant grains easily occurred and (3) with regard to the total Cd amounts and the mobility characteristics in paddy soils (Rogan Šmuc 2010), Cd was mostly accumulated in the plant roots.

Dietary risk assessment (estimated daily intake amounts) for the Kočani area population

For calculating the daily intake amount values, we employed only heavy metals that exceeded the permissible limit values for rice and maize crops: As, $\mathrm{Cd}, \mathrm{Mo}, \mathrm{Pb}$ and $\mathrm{Zn}$. Hence, Table 9 lists the mean and maximum $\mathrm{As}, \mathrm{Cd}, \mathrm{Mo}, \mathrm{Pb}$ and $\mathrm{Zn}$ concentrations defined in rice and mean and maximum $\mathrm{Mo}$ and $\mathrm{Pb}$ concentrations detected in maize samples. The maximum concentrations of $\mathrm{As}, \mathrm{Cd}, \mathrm{Mo}, \mathrm{Pb}$ and $\mathrm{Zn}$ were measured in the rice and maize samples grown in the vicinity of the Zletovska River. The estimated daily intake amount values for Kočani Field are listed in Table 10.

The trends of maximum and mean concentrations for $\mathrm{As}, \mathrm{Cd}, \mathrm{Mo}, \mathrm{Pb}$ and $\mathrm{Zn}$ in investigated samples were in the order rice $>$ maize, signifying higher intake values for rice.

By consuming the crops grown in the whole area of Kočani Field, an adult will intake $0.12 \mathrm{mg}$ of As, $0.03 \mathrm{mg}$ of $\mathrm{Cd}, 0.18 \mathrm{mg}$ of $\mathrm{Mo}, 0.18 \mathrm{mg}$ of $\mathrm{Pb}$ and $12.3 \mathrm{mg}$ of $\mathrm{Zn}$ per day (Table 10). These values are lower than the recommended PTDI levels and, therefore, not harmful to local inhabitants.

However, by consuming crops grown only in the area around the Zletovska River, the situation is entirely different. An adult will intake $0.23 \mathrm{mg}$ of As, $0.14 \mathrm{mg}$ of $\mathrm{Cd}, 0.63 \mathrm{mg}$ of $\mathrm{Mo}, 0.83 \mathrm{mg}$ of $\mathrm{Pb}$ and $29.5 \mathrm{mg}$ of $\mathrm{Zn}$ per day, which means that the daily intake amount values of $\mathrm{Cd}, \mathrm{Mo}, \mathrm{Pb}$ and $\mathrm{Zn}$ exceed PTDI values (Table 10). The results showed that the regular consumption of rice and maize crops 
Table 9 Mean (all samples) and maximum (samples around Zletovska River) values of As, $\mathrm{Cd}, \mathrm{Mo}, \mathrm{Pb}$ and $\mathrm{Zn}$ defined in rice (R) and maize (M) samples

\begin{tabular}{llllll}
\hline Element $(\mathrm{mg} / \mathrm{g})$ & As & Cd & Mo & $\mathrm{Pb}$ & $\mathrm{Zn}$ \\
\hline Mean values R & 0.279 & 0.069 & 0.46 & 0.196 & 27.86 \\
Max values R & 0.53 & 0.31 & 0.7 & 0.5 & 67 \\
Mean values M & - & - & 0.37 & 0.2 & - \\
Max values M & - & - & 0.73 & 1.38 \\
\hline
\end{tabular}

Table 10 The estimated daily intake amount (DIA) values for rice (R) and maize (M) samples from Kočani Field area (Total DIA $=$ DIA R + DIA M)

\begin{tabular}{llllll}
\hline Element (mg/day) & As & Cd & Mo & Pb & Zn \\
\hline DIA R (mean) & 0.12 & 0.03 & 0.20 & 0.09 & 0.22 \\
DIA R (max) & 0.23 & 0.14 & 0.31 & 0.09 & 29.5 \\
DIA M (mean) & - & - & 0.16 & 0.61 & - \\
DIA M (max) & - & - & 0.32 & 0.18 & 0.83 \\
Total DIA (mean) & 0.12 & 0.03 & 0.63 & 0.429 \\
Total DIA (max) & 0.23 & 0.14 & $0.044-0.460$ & 29.5 \\
PTDI (WHO) & 0.58 & 0.072 & & 15 \\
\hline
\end{tabular}

containing the highest $\mathrm{Cd}, \mathrm{Mo}, \mathrm{Pb}$ and $\mathrm{Zn}$ concentrations could pose a serious threat to human health.

\section{Conclusions}

The highest $\mathrm{As}, \mathrm{Cd}, \mathrm{Mo}, \mathrm{Pb}$ and $\mathrm{Zn}$ values, which exceeded the maximum permissible levels, were detected in the rice samples grown in the paddy fields near the Zletovska River (Section VII). The highest $\mathrm{Pb}$ and Mo concentrations, which also exceeded the maximum permissible values, were present in the maize samples from the corn fields near the Zletovska River $(\mathrm{Pb})$ and Ciflik city (Mo). This situation is connected with the fact that paddy soils located in the vicinity of the Zletovska River contain very high amounts of these heavy metals. Moreover, the locations around the city of Ciflik are probably polluted with Mo not only because of irrigation with polluted riverine water, but also from traffic and geogenic Mo sources.

The heavy metal concentrations in rice samples were generally higher than those in maize samples. This distinction could be explained by the fact that heavy metal amounts vary within plant species and that the rice grains were sampled in 2005 when the pollution law about mining activities had not yet been passed and the anthropogenic effects from the Sasa tailing dam accident remained high. Maize grain samples were collected in 2008.

High TF values for $\mathrm{Mo}, \mathrm{Zn}, \mathrm{Cd}$ and $\mathrm{Cu}$ revealed a medium accumulation of $\mathrm{Mo}, \mathrm{Zn}$ and $\mathrm{Cd}$ by rice and $\mathrm{Mo}, \mathrm{Zn}$ and $\mathrm{Cu}$ by maize. The TF results generally confirmed the sequential extraction results, but regarding the differences, we discovered the following: (1) Mo was highly mobile (according to the other elements studied) in the plants growing in the Kočani Field area, (2) in the Kočani Field plant samples, the translocation process of $\mathrm{Zn}$ from soils, roots to plant grains had occurred and (3) Cd was probably mostly accumulated in the plant roots.

The results showed that the regular consumption of rice and maize crops containing the highest $\mathrm{Cd}$, Mo, $\mathrm{Pb}$ and $\mathrm{Zn}$ concentrations could pose a serious threat to human health, because the daily intake of $\mathrm{Cd}, \mathrm{Mo}, \mathrm{Pb}$ and $\mathrm{Zn}$ for crops grown in the fields around the Zletovska River exceeded recommended PTDI values.

According to the results, the area around Zletovska River is considered as the most anthropogenically impacted part of Kočani Field region. Thus, an urgent and systematic study on heavy metal concentrations in drinking water and other edible crops in Kočani Field area is essential. 
Acknowledgments The research was financially supported by the Slovenian Research Agency (ARRS), contract number 100005-310229.

\section{References}

Adriano, D. C. (1986). Trace elements in the terrestrial environment (1st ed.). New York: Springer.

Adriano, D. C. (2001). Trace elements in terrestrial environments: Biogeochemistry, bioavailability and risks of metals (2nd ed.). New York: Springer.

Alderton, D. H. M., Serafimovski, T., Mullen, B., Fairall, K., James, S., et al. (2005). The chemistry of waters associated with metal mining in Macedonia. Mine Water Environment, 24, 139-149.

Alloway, B. J. (1990). Heavy metals in soils. New Jersey: Blackie \& Son.

CAC. (2002). Report of the 34th session of the Codex Committee on food additives and contaminants. The Netherlands: Rotterdam.

Chen, T. B., Wong, J. W. C., Zhou, H. Y., Wong, M. H., et al. (1997). Assessment of trace metal distribution and contamination in surface soils of Hong Kong. Environmental Pollution, 96, 61-68.

Cheng, F. M., Zhao, N. C., Xu, H. M., et al. (2006). Cadmium and lead contamination in japonica rice grains and its variation among the different locations in southeast China. Science of the Total Environment, 359, 156-166.

Commission Regulation Directive EC. (2001). Commission Regulation (EC) no. 466. Official Journal of the European Communities.

Cui, Y. J., Zhu, Y. G., Zhai, R. H., Chen, D. Y., Huang, Y. Z., Qui, Y., et al. (2004). Transfer of metals from soil to vegetables in an area near a smelter in Nanning, China. Environment International, 30(6), 785-791.

Dean, J. R. (2007). Bioavailability, bioaccessibility and mobility of environmental contaminants (1st ed.). London: Wiley.

Dolenec, T., Serafimovski, T., Tasev, G., Dobnikar, M., Dolenec, M., Rogan, N., et al. (2007). Major and trace elements in paddy soil contaminated by $\mathrm{Pb}-\mathrm{Zn}$ mining: A case study of Kočani Field, Macedonia. Environmental Geochemistry and Health, 29, 21-32.

FAO/WHO. (1992). Cadmium (EHC no. 134). Geneva, Switzerland.

Jung, M. C. (2001). Heavy metal contamination of soils and waters in and around the Imcheon $\mathrm{Au}-\mathrm{Ag}$ mine, Korea. Applied Geochemistry, 16, 1369-1375.

Jung, M. C., \& Thornton, I. (1996). Heavy metal contamination of soils and plants in the vicinity of a lead-zinc mine, Korea. Applied Geochemistry, 11, 53-59.

Jung, M. C., \& Thornton, I. (1997). Environmental contamination and seasonal variation of metals in soils, plants and waters in the paddy fields around a $\mathrm{Pb}-\mathrm{Zn}$ mine in Korea. Science of the Total Environment, 198, 105-121.

Kabata-Pendias, A., \& Pendias, H. (2001). Trace elements in soils and plants (3rd ed.). Boca Raton: CRC Press.

Kachenko, A. G., \& Singh, B. (2006). Heavy metals contamination in vegetables grown in urban and metal smelter contaminated sites in Australia. Water, Air, and Soil Pollution, 169, 101-123.

Khan, S., Cao, Q., Zheng, Y. M., et al. (2008). Health risks of heavy metals in contaminated soils and food crops irrigated with wastewater in Beijing, China. Environmental Pollution, 158, 686-692.

Korre, A., Durucan, S., Koutroumani, A., et al. (2002). Quantitative-spatial assessment of the risks associated with high $\mathrm{Pb}$ loads in soils around Lavrio, Greece. Applied Geochemistry, 17, 1029-1045.

Lee, C. G., Chon, H. T., Jung, M. C., et al. (2001). Heavy metal contamination in the vicinity of the Daduk $\mathrm{Au}-\mathrm{Ag}-\mathrm{Pb}-\mathrm{Zn}$ mine in Korea. Applied Geochemistry, 16, 1377-1386.

Li, X. D., \& Thornton, I. (1993). Arsenic, antimony and bismuth in soil and pasture herbage in some old metalliferous mining areas in England. Environmental Geochemistry and Health, 15, 135-144.

Liu, H., Probst, A., Liao, B., et al. (2005). Metal contamination of soils and crops affected by the Chenzhou lead/zinc mine spill (Hunan, China). Science of the Total Environment, 339, 153-166.

Lu, X., \& Zhang, X. (2005). Environmental geochemistry study of arsenic in Western Hunan mining area, P.R. China. Environmental Geochemistry and Health, 27, 313-320.

McLaughlin, M. J., Parker, D. R., Clarke, J. M., et al. (1999). Metals and micronutrients-Food safety issues. Field Crops Research, 60, 143-163.

Pilc, L., Rosada, J., Siepak, J., et al. (1994). Heavy metals concentration in soil, water and plants in the emission region of copper foundry "Glogów". Materiaty Sesji Naukowej Instytutu Ochrony Roslin, 2, 228-232.

Pruvot, C., Douay, F., Herve, F., Waterlot, C., et al. (2006). Heavy metals in soil, crops and grass as a source of human exposure in the former mining areas. Journal of Soils and Sediments, 6, 215-220.

Rogan, N., Serafimovski, T., Dolenec, M., Tasev, G., Dolenec, T., et al. (2009). Heavy metal contamination of paddy soils and rice (Oryza sativa L.) from Kočani field (Macedonia). Environmental Geochemistry and Health, 31, 439-451.

Rogan Šmuc, N. (2010). Heavy metal contamination of soils and crops in tertiary basins: A case study of Kočani Field (Macedonia). Dr. thesis, 108 pp.

Rogan Šmuc, N., Vrhovnik, P., Dolenec, T., Serafimovski, T., Tasev, G., Dolenec, M., et al. (2009). Assessment of the heavy metal contamination in the surficial sediments of Lake Kalimanci (Macedonia): A preliminary study. RMZMaterials and Geoenvironment, 56, 437-447.

Rose, A. W., Hawkes, H. E., Webb, J. S., et al. (1979). Geochemistry and mineral exploration (2nd ed.). London: Academic Press.

Simmons, R. W., Pongsakul, P., Saiyasitpanich, D., Klinphoklap, S., et al. (2005). Elevated levels of cadmium and zinc in paddy soils and elevated levels of cadmium in rice grain downstream of a zinc mineralized area in Thailand: Implications for public health. Environmental Geochemistry and Health, 27, 501-511.

Wang, G., Su, M. Y., Chen, Y. H., et al. (2006). Transfer characteristics of cadmium and lead to the edible parts of six vegetable species in southeastern China. Environmental Pollution, 144, 127-135. 
WHO. (1998). Copper. Environmental Health Criteria no. 200. Geneva, Switzerland.

Witte, K. M., Wanty, R. B., Ridley, W. I., et al. (2004). Engelman spruce (Picea engelmannii) as abiological monitor of changes in soil metal loading related to past mining activity. Applied Geochemistry, 19, 1367-1376.

Wong, S. C., Li, X. D., Zhang, G., Qi, S. H., Min, Y. S., et al. (2002). Heavy metals in agricultural soils of the Pearl River Delta, South China. Environmental Pollution, 119, 33-44.
Yang, Q. W., Shu, W. S., Qiu, J. W., Wang, H. B., Lan, C. Y., et al. (2004). Lead in paddy soils and rice plants and its potential health risk around Lechang Lead/Zinc Mine, Guangdong, China. Environment International, 30, 883889.

Zhuang, P., McBride, M. B., Xia, H., Li, N., Li, Z., et al. (2009). Health risk from heavy metals via consumption of food crops in the vicinity of Dabaoshan mine, South China. Science of the Total Environment, 407, 1551-1561. 